NOTE

\title{
A population of giant tailed virus-like particles associated with heterotrophic flagellates in a lake-type reservoir
}

\author{
Markus G. Weinbauer ${ }^{1,2, *}$, John R. Dolan ${ }^{1,2}$, Karel Šimek ${ }^{3}$ \\ ${ }^{1}$ Sorbonne Universités, UPMC Univ Paris 06, UMR 7093, LOV, Observatoire océanologique, 06230 Villefranche/mer, France \\ ${ }^{2}$ CNRS, UMR 7093, LOV, Observatoire océanologique, 06230 Villefranche/mer, France \\ ${ }^{3}$ Biology Centre CAS, v.v.i., Hydrobiological Institute, Na Sádkách 7, 37005 České Budějovice, Czech Republic
}

\begin{abstract}
Using transmission electron microscopy (TEM), a population of giant virus-like particles (VLPs) with a head diameter of ca. $405 \mathrm{~nm}$ and a flexible ca. $1100 \mathrm{~nm}$ long tail was detected in a lake-type reservoir. These giant VLPs were abundant in situ at the start of a survey period $\left(3.3 \times 10^{4}\right.$ particles $\left.\mathrm{ml}^{-1}\right)$ and increased by 7 -fold within $96 \mathrm{~h}$. This VLP population vanished in dialysis bag incubations of $0.8 \mu \mathrm{m}$-filtered reservoir water (free of bacterivorous flagellates) but increased markedly in the enhanced bacterivory treatment, i.e. $5 \mu \mathrm{m}$ filtered water. In the latter, incubation, heterotrophic nanoflagellate (HNF) abundance increased approximately 15 -fold during the study. A multiple regression analysis using microbial abundances and grazing rates as parameters indicated that $78 \%$ of the variability in the abundance of giant VLPs was explained by HNF abundance and grazing rates. Our data support the hypothesis that this virus population infects flagellates. Observation of a presumptive lysing flagellate cell suggests a viral burst size of 15. Estimations of decay and net production rates from dialysis bag incubations indicate that lysis due to giant viruses could cause between 10 to $60 \%$ of the mortality of the total flagellate community and, thus, viruses are potentially a significant factor shaping the population dynamics of flagellates in freshwater.
\end{abstract}

KEY WORDS: Viral infection $\cdot$ Mortality $\cdot$ Burst size

\section{INTRODUCTION}

Flagellates are usually the major consumers of auto- and heterotrophic bacterioplankton thus, linking bacteria with the grazing food chain, and they are significant remineralizers of inorganic nutrients (Hahn \& Höfle 2001, Montagnes et al. 2008). Consequently, heterotrophic nanoflagellates (HNF) are a key component of pelagic ecosystems (e.g. Azam et al. 1983). In limnetic systems, population densities of flagellates are thought to be controlled by grazers, specifically larger protists such as ciliates, and larger zooplankton such as rotifers, copepods, and cladocerans (Jürgens et al. 1997, Jürgens \& Jeppesen 2000, Sommer et al. 2012, Šimek et al. 2014). During the last two and a half decades, a plethora of information has been accumulated on viruses controlling bacterioplankton (e.g. Weinbauer 2004, Winter et al. 2010) and phytoplankton (e.g. Brussaard 2004, Brussaard et al. 2008, Sharoni et al. 2015). However, our knowledge of the viruses of non-photosynthetic protists (such as HNF and ciliates) is still sparse and mainly 
restricted to investigations of a few isolated virushost systems (e.g. Nagasaki et al. 1993, Garza \& Suttle 1995, Massana et al. 2007).

During an in situ survey and an experiment performed in the mesotrophic lake-type Římov Reservoir (South Bohemia, Czech Republic) to assess the role of protistan grazing on bacterial community dynamics and composition and on viral infection of bacterioplankton (Šimek et al. 2001), we detected a morphologically distinct giant virus-like particle (VLP) population (potentially infecting flagellates) and followed its development in situ and estimated decay and potential production rates.

\section{MATERIALS AND METHODS}

The in situ study and the experiment were conducted in the meso-eutrophic Rímov Reservoir (for details, see Šimek et al. 2001). The sampling site is located above the former river valley (water depth $30 \mathrm{~m}$ ), about $250 \mathrm{~m}$ from the reservoir dam. On 28 May 1999, water samples were collected with a 21 Friedinger sampler from a depth of $0.5 \mathrm{~m}$ and a final volume of $30 \mathrm{l}$ was pooled in a $50 \mathrm{l}$ plastic container. The water temperature was ca. $19^{\circ} \mathrm{C}$.

The experiment was run during the late clear-water phase (28 May to 1 June 1999), i.e. when phytoplankton populations are relatively sparse due to increased predation pressure of large filter-feeding zooplankton (Sommer et al. 2012). For the experiment water samples were sequentially size fractionated through 5 and $0.8 \mu \mathrm{m}$ poresize Poretics filters (diameter $47 \mathrm{~mm}$; OSMONIC.) producing 2 fractions: $<5 \mu \mathrm{m}$ (viruses, bacteria and HNF only) and $<0.8 \mu \mathrm{m}$ (viruses and bacteria only). These 2 fractions represent (1) a treatment with enhanced bacterivory due to removal of predators of bacterivorous flagellates and (2) a bacterivore-free treatment (Šimek et al. 2001). The $0.8 \mu \mathrm{m}$ filtration step was conducted in sterilized glass Poretics filter holders to avoid contamination by small flagellates. The water fractions were placed in 21 pre-treated (distilled water rinsed and boiled) dialysis tubes (diameter $75 \mathrm{~mm}$, molecular mass cutoff 12000 to $16000 \mathrm{Da}$; Poly Labo). The dialysis bags were incubated in the reservoir at a depth of $0.5 \mathrm{~m}$, oriented horizontally in open Plexiglas holders. Dialysis bags were used to allow exchange of nutrients and small dissolved organic matter with ambient reservoir water. Samples for monitoring in situ conditions in the reservoir water were also collected during the study period. The experimental design and protocol are described in detail in Šimek et al. (2001). Briefly, samples (250 to $300 \mathrm{ml}$ ) were taken from each dialysis bag and reservoir water at $0,12,24,48,72$, and $96 \mathrm{~h}$, fixed with formaldehyde ( $2 \%$ final concentration). Sample aliquots for enumerations using epifluorescence microscopy were examined within $4 \mathrm{~h}$ of sampling. For enumerations of giant virus-like particles (VLPs) by transmission electron microscopy (TEM), aliquots were stored at $4^{\circ} \mathrm{C}$ for $7 \mathrm{~d}$ until analysis.

Giant VLPs were enumerated using TEM as described previously (Weinbauer et al. 1993). Briefly, viruses were collected quantitatively onto Formvarcoated, 400 mesh electron microscope grids by centrifugation in a swinging-bucket rotor (Sorval TH-641; $100000 \times g$ for $2.5 \mathrm{~h}$ ), stained for $30 \mathrm{~s}$ with $1 \%$ (wt/vol) uranyl acetate, and rinsed 3 times with deionized distilled water. Head-size diameters and tail parameters of giant VLPs were determined from photomicrographs (magnification 30000 to $140000 \times$ ) analyzed under a dissecting lens (10×) (Weinbauer et al. 1993). For counting by using epifluorescence microscopy, VLPs were stained with SYBR Green I (10 000 $x$ in dimethyl sulfoxid). Bacteria, HNF and ciliates were stained with 4-6-diamidino-2-phenylindole (DAPI) (final concentration $0.1 \mathrm{~g} \mathrm{ml}^{-1}$ ) and counted by epifluorescence microscopy. For details of preservation and enumeration see (Šimek et al. 2001). Briefly, plastidcontaining flagellates were enumerated in samples preserved with Lugol's solution, cleared with sodium thiosulphate, employing the Utermöhl method and an inverted microscope (Lund et al. 1958).

\section{RESULTS AND DISCUSSION}

In the grazer-free treatment $(<0.8 \mu \mathrm{m})$, bacterial numbers increased between 12 and $48 \mathrm{~h}$ (Fig. 1D). Bacterial dynamics in the $<5 \mu \mathrm{m}$ treatment showed different trends. After a slight initial increase, bacterial abundance dropped between 24 and $96 \mathrm{~h}$ (Fig. 1E). Compared to the $<0.8$ and $<5 \mu \mathrm{m}$ treatments, whole-water samples from the reservoir showed negligible changes in bacterial abundance (Fig. 1F). Marked differences in total VLP abundance were found among the $<0.8 \mu \mathrm{m},<5 \mu \mathrm{m}$, and reservoir populations (Fig. 1D-F). Total VLP abundance appeared to vary inversely with bacterial abundance. For instance, by the end of the experiment in the heavily grazed $<5 \mu \mathrm{m}$ treatment, the largest numbers of total VLPs $\left(47 \times 10^{6} \mathrm{ml}^{-1}\right)$ were detected, along with the lowest bacterial abundance. In contrast, samples from the grazer-free treatment $(<0.8 \mu \mathrm{m})$, in which bacteria became most abundant, yielded the lowest estimates of total VLP abundance $\left(17 \times 10^{6} \mathrm{ml}^{-1}\right)$. As opposed to 

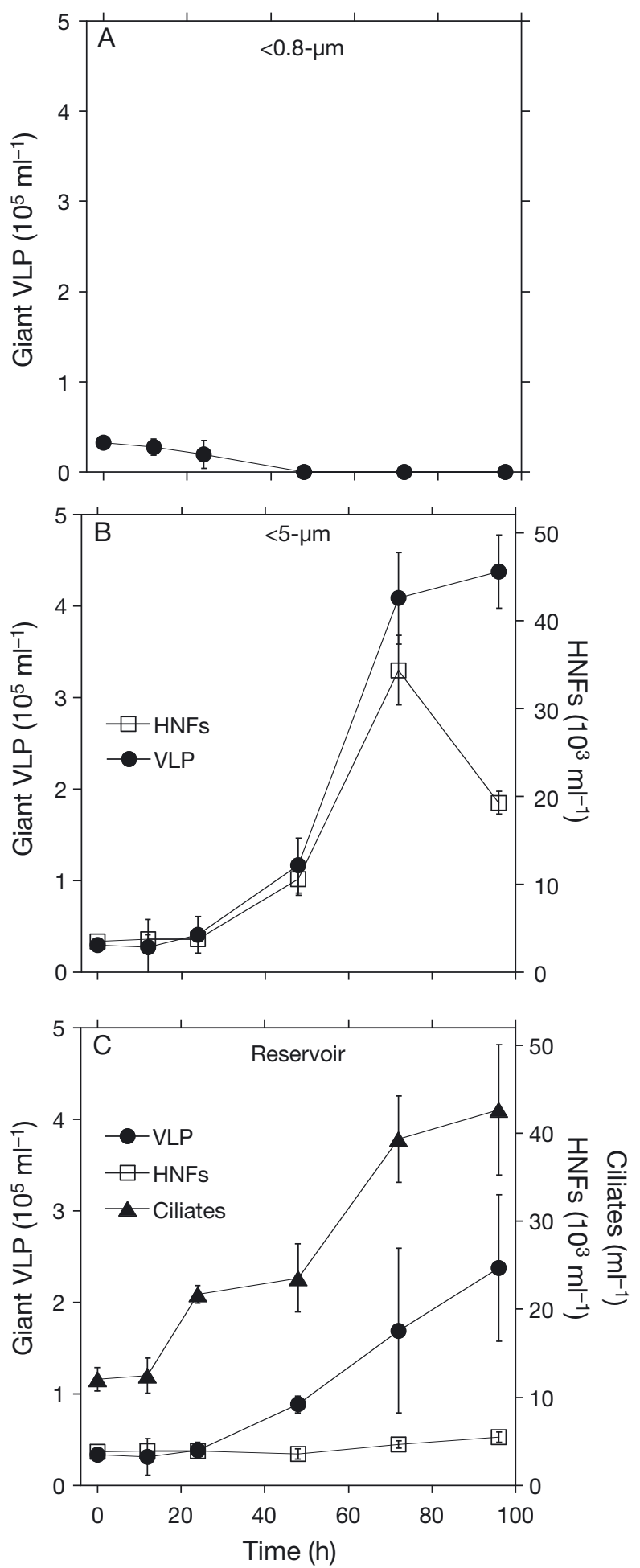
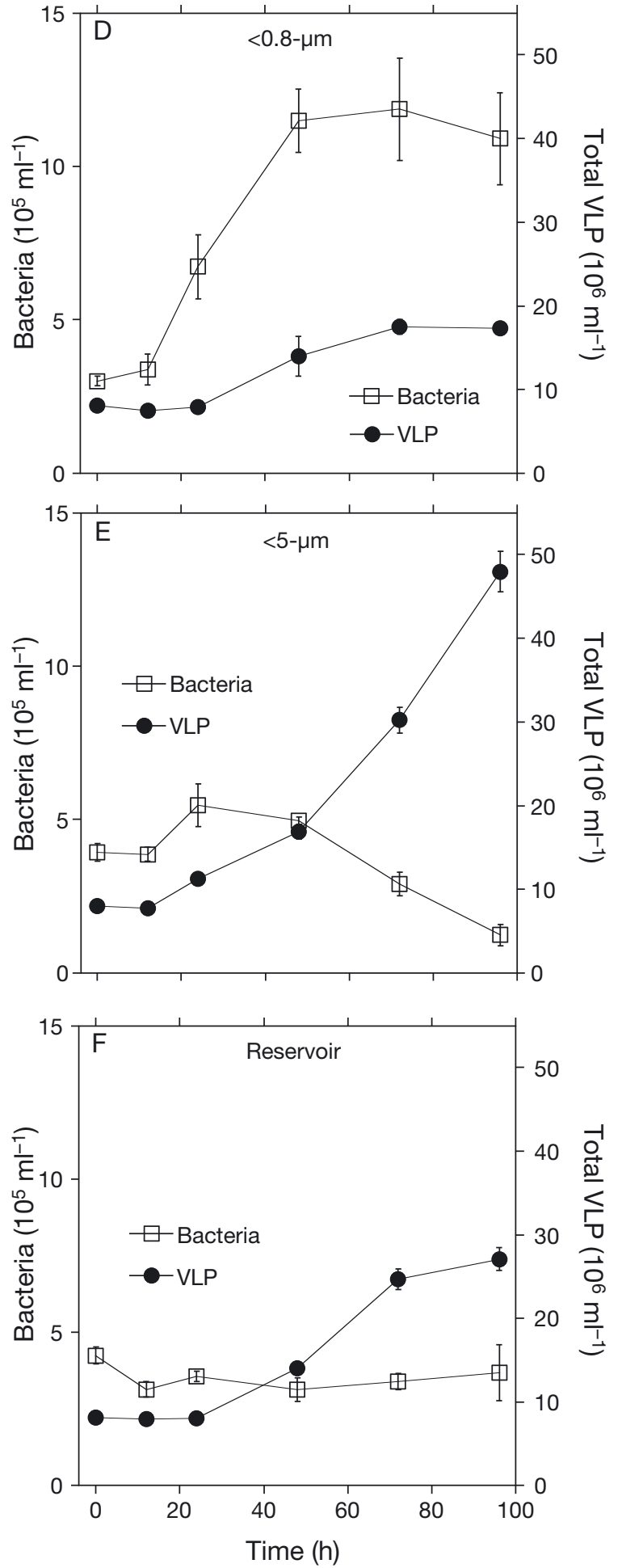

Fig. 1. Time-course changes in the abundance of bacteria, total virus-like particles (VLPs), giant VLPs, heterotrophic nanoflagellates (HNFs) and ciliates in size fractionation treatments $(<0.8$ and $<5 \mu \mathrm{m})$ of reservoir water incubated in the reservoir in dialysis bags compared to in situ reservoir water: (A) giant VLPs in $<0.8 \mu \mathrm{m}$ treatment; (B) giant VLPs and HNFs in $<5 \mu \mathrm{m}$ treatment; (C) giant VLPs, HNFs and ciliates in unfiltered water; total VLPs and bacteria in (D) $<0.8 \mu \mathrm{m},(\mathrm{E})<0.5 \mu \mathrm{m}$ treatments and (F) unfiltered water. Bacterial, VLP and HNF and ciliate abundance values are the means of 3 replicates; error bars indicate SD. The values for giant viruses are the means of triplicate subsamples from a single pooled sample representing all 3 replicates; the vertical bars show the SD of triplicate estimates (i.e. 3 TEM grids) 
the markedly distinct trends between the grazer-free $(<0.8 \mu \mathrm{m})$ and grazerenhanced $(<5 \mu \mathrm{m})$ treatments, samples from the reservoir differed little from the $<5 \mu \mathrm{m}$ samples. In both reservoir and $<5 \mu \mathrm{m}$ treatment samples, total VLP abundance increased steadily from $24 \mathrm{~h}$ to $72 \mathrm{~h}$ and then declined slightly; in contrast to the $<0.8 \mu \mathrm{m}$ treatment, in which total VLP abundances were relatively invariant. The total VLP to bacteria ratio ranged from 19 to 93 in the reservoir, which is close to the value of 21 obtained when using flash-freezing of samples in liquid nitrogen from the same environment

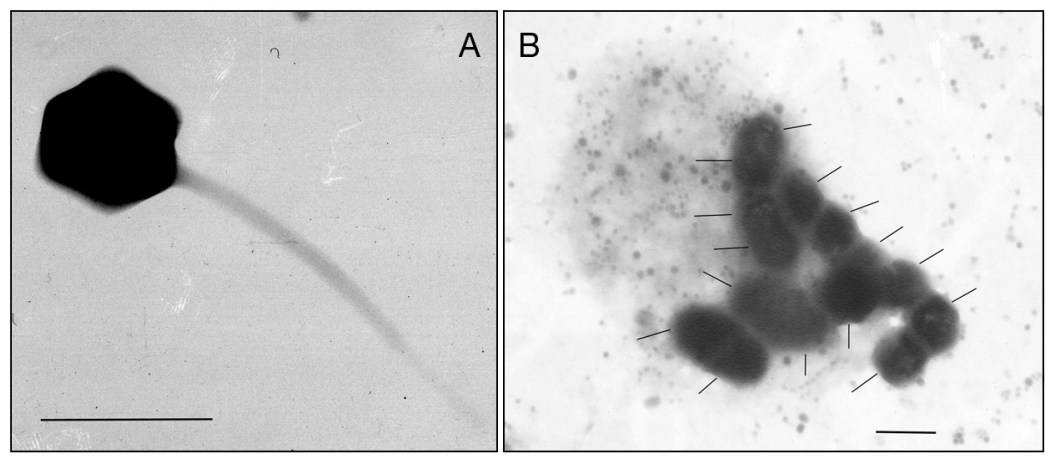

Fig. 2. Electron micrograph of giant tailed viruses (A) and a potentially lysing flagellate (B). Scale bars $=500 \mathrm{~nm}$. Note that the seemingly elongated dimension of some particles is a photographic artifact, which becomes evident by changing the plane of focus during TEM inspection, revealing 2 distinct viral particles. Dashes point to the different VLPs

(Weinbauer et al. 2007).

At the start of the study, in situ HNF and ciliate abundances were $3.8 \times 10^{3}$ and $12 \times 10^{3}$ cells ml $^{-1}$, respectively. HNF abundance increased slightly, whereas ciliate abundance showed a 3.6 fold increase during the $96 \mathrm{~h}$ survey period (Fig. 1C). In the $0.8 \mu \mathrm{m}$ treatment, no HNFs were observed in any samples taken during the experiment. In the $5 \mu \mathrm{m}$ treatments, HNF abundance increased by about one order of magnitude to values of $34.3 \times 10^{3} \mathrm{ml}^{-1}$ but decreased at the end of the incubation; no ciliates were detected in this treatment (Fig. 1B). Plastid-containing, potentially mixotrophic flagellates were present at very low abundances in situ (a few Dinobryon sp. cells $\mathrm{ml}^{-1}$ ) and in the experiments. Numbers of photosynthetic flagellates (largely Rhodomonas minuta; P. Znachor et al. unpubl.) were also well below 500 cells $\mathrm{ml}^{-1}$, i.e. at the very low abundance typical for the clear water phase (Šimek et al. 2008). The HNF community was dominated by bacterivorous Spumella-like chrysophytes. One can assume shifts of a HNF community towards the dominance of HNFs best adapted to a bacterial community developing in experimentally manipulated $(<5 \mu \mathrm{m})$ treatments without top-down control by larger zooplankton (Šimek et al. 2013). A sudden experimentally induced pulse in bacterial food availability was also proposed as a driving force for a rapid shift of an HNF community towards dominance of several Spumella-like phylotypes in the Rímov Reservoir (Šimek et al. 2013). Ciliates were dominated by small algivorous prostomes (Urotricha spp. and Balanion sp.) and omnivorous oligotrichs (Rimostrombidium sp. and Halteria grandinella), i.e. ciliates with an equivalent cell diameter of 15 to $20 \mu \mathrm{m}$.

We found morphologically distinct VLPs with a head diameter of $405 \pm 31 \mathrm{~nm}$ and a tail or remnants of a tail. The tail appeared flexible, had a diameter of ca. $70 \mathrm{~nm}$ and a length of ca. $1100 \mathrm{~nm}$ (Fig. 2A). The average head diameter of the total viral community was only ca. $65 \mathrm{~nm}$ (M. G. Weinbauer unpubl. data) and thus similar to other limnetic oxic environments, where the average capsid diameter is typically within the range of 60 to $70 \mathrm{~nm}$ (Weinbauer 2004). The VLPs constituting the distinct population can be classified as giant viruses, since this class of viruses was initially defined as having capsid diameters $>300 \mathrm{~nm}$ (Bratbak et al. 1992).

The abundance of the giant VLP population was $3.3 \times 10^{4} \mathrm{ml}^{-1}$ in situ and increased 7 -fold during the survey period (Fig. 1C). The corresponding net production rate (calculated from the slope of a linear regression analysis of $\ln$ transformed data) was $0.70 \pm$ $0.235 \mathrm{~d}^{-1}$. In the $<0.8 \mu \mathrm{m}$ treatment with undetectable HNF concentrations, the abundance of giant VLPs decreased during the experiment and fell below the detection limit after $2 \mathrm{~d}$ (Fig. 1A). The decay rate was $0.50 \pm 0.216 \mathrm{~d}^{-1}$. In the $<5 \mu \mathrm{m}$ treatment, the abundance of giant viruses increased $15-$ fold (Fig. 1B) corresponding to a net production rate of $1.08 \pm 0.288 \mathrm{~d}^{-1}$. Production rates of giant VLPs (calculated as net production rates plus decay rates) were $1.2 \mathrm{~d}^{-1}$ in the reservoir and $1.6 \mathrm{~d}^{-1}$ in the $<5 \mu \mathrm{m}$ treatment. Absolute values of viral counts by TEM or epifluorescence microscopy might be an underestimation, e.g. due to storage at $4^{\circ} \mathrm{C}$ (Hennes \& Suttle 1995, Wen et al. 2004). However, storage time before ultracentrifugation onto TEM grids was identical for all samples; thus, relative differences between treatments and rates should not be affected by such problems. In addition, large viruses seem to have lower decay rates than the average virus community (Heldal \& Bratbak 1991). 
Using published data of total VLPs from the reservoir at the sampling time (see also Fig. 1), the proportion of giant VLP as a fraction of total viral abundance in situ was ca. $0.3 \%$. As a comparison, estimates of viruses with a capsid diameter of $>100 \mathrm{~nm}$ in marine and limnetic systems range from $<1$ to $10 \%$ (Weinbauer 2004). The abundance of giant VLPs was correlated (Spearman rank correlation) with total grazing rates $(\rho=0.95 ; p<0.0001)$ and HNF abundance $(\rho=0.80, p<0.001)$. Other parameters such as total VLP abundance, bacterial abundance and total and cell-specific bacterial production (production data obtained from Šimek et al. 2001) showed no significant correlation with giant VLPs ( $p>0.05)$. A multiple regression analysis of these parameters was significant $\left(\mathrm{r}^{2}=0.78, \mathrm{p}<0.001\right)$ and confirmed the Spearman rank correlation analysis. The result of the multiple regression analysis was calculated as:

$$
\mathrm{VA}_{\mathrm{g}}=0.54-0.34 \times \mathrm{FA}+1.91 \times \mathrm{GR}
$$

where $\mathrm{VA}_{\mathrm{g}}$ is abundance of giant VLPs $\left(10^{4}\right.$ particles $\left.\mathrm{ml}^{-1}\right), \mathrm{FA}$ is HNF abundance $\left(10^{3}\right.$ cells $\left.\mathrm{ml}^{-1} \mathrm{~d}^{-1}\right)$ and GR is the grazing rate $\left(10^{6}\right.$ bacteria $\left.\mathrm{ml}^{-1} \mathrm{~d}^{-1}\right)$. GR was measured by the fluorescently labeled bacteria approach and data were obtained from Šmek et al. (2001).

The following lines of evidence suggest that the giant VLPs infect HNFs: First, large viruses vanished in the HNF-free <0.8 um treatment, indicating that no giant VLPs were produced when no flagellates were present. Second, giant VLP abundances were higher in the $<5 \mu \mathrm{m}$ treatments than in the reservoir, i.e. they were highest at the most elevated HNF abundances. Third, the capsid size of giant VLPs was more than 4 times larger than the capsid size of viruses detected in bacterial cells by TEM in the same samples (M. G. Weinbauer unpubl. data). Fourth, the abundance of large viruses was only significantly related to HNF abundance and grazing rate (explaining $78 \%$ of the variation in a statistical sense) and not to bacterial or ciliate parameters, thus suggesting an HNF origin of the giant VLPs. Finally, a TEM picture indicates a eukaryotic rather than a bacterial cell as host (for details see below).

The size of particles in the plankton is a major factor influencing contact rates between viruses and cells (Murray \& Jackson 1992). Thus, the large head and tail size of giant VLPs could increase contact rates. This can be seen as adaptations of giant VLPs to low (relative to bacteria) host abundances. In addition, giant VLPs fall well within the optimum size range of food for HNFs (Šimek et al. 2001), particularly when regarding not only capsid size but also tail length. Thus, on the one hand grazing of giant VLPs could be a (moderate) source of C, N and P for HNFs (and ciliates) (González \& Suttle 1993, Bettarel et al. 2005) and, on the other hand, grazing could be a defense against lytic infection by giant VLPs (unless infection occurs in the food vacuole). Alternatively, induction of cells with a latent infection as mechanisms of viral production (Massana et al. 2007) cannot be excluded; however, potential induction agents remain unknown.

The potential virus-induced mortality of HNFs (VMF) due to lysis by giant VLPs was calculated as:

$$
\mathrm{VMF}=100 \times\left[\left(\mu \mathrm{VA}_{\mathrm{g}} \times \mathrm{VA}_{\mathrm{g}} / \mathrm{BS}\right) /(\mu \mathrm{FA} \times \mathrm{FA})\right]
$$

where $\mathrm{VA}_{\mathrm{g}}$ and FA are abundances at the start of the in situ survey (Fig. 1), $\mu \mathrm{VA}_{\mathrm{g}}$ is the growth rate of giant VLPs (Table 1), $\mu$ FA is the growth rate of HNF, estimated at $1.59 \mathrm{~d}^{-1}$ in the experiment (Šimek et al. 2001) and BS is the burst size, using the value of 70 estimated by Massana et al. (2007). VMF was calculated as $0.57 \times 10^{3}$ cells $\mathrm{ml}^{-1} \mathrm{~d}^{-1}(9.4 \%)$ in situ and $0.71 \times 10^{3}$ cells ml ${ }^{-1} \mathrm{~d}^{-1}(12.5 \%)$ in the $<5 \mu \mathrm{m}$ treatment. Viruses typically infect only a small range of eukaryotic hosts (Massana et al. 2007). Thus, the mortality rates have to be considered as a conservative estimate. In addition, our data might be an underestimation, since the loss of infectivity is likely higher than the loss (decay) of particles. Also, the BS we used might be an overestimation, since BS is typically elevated in isolated virus-host systems compared to in situ (Børsheim 1993). A TEM micrograph from the $<5 \mu \mathrm{m}$ treatment of our experiment shows a group of VLPs identical in size to the giant VLPs embedded in an organic matrix (Fig. 2B). Note that the seemingly elongated dimensions of some particles is a photographic artifact, which becomes evi-

Table 1. Production and decay rates $\left(\mathrm{d}^{-1}\right)$ of total and giant VLPs in incubations of filtered $(<0.8$ and $<5 \mu \mathrm{m})$ and in situ reservoir water. Positive values indicate production, negative values indicate decay. Values for net production/decay are mean \pm SD. Production rates in the final column are calculated by adding mean decay rates of particles (as estimated in the $<0.8 \mu \mathrm{m}$ treatment) to net production rates. NA: not applicable

\begin{tabular}{|lccc} 
Treatment & $\begin{array}{c}\text { Net production } \\
\text { of total VLPs } \\
\left(\mathrm{d}^{-1}\right)\end{array}$ & $\begin{array}{c}\text { Net production/ } \\
\text { decay of giant } \\
\text { VLPs }\left(\mathrm{d}^{-1}\right)\end{array}$ & $\begin{array}{c}\text { Production } \\
\text { of giant } \\
\text { VLPs }\left(\mathrm{d}^{-1}\right)\end{array}$ \\
\hline$<0.8 \mu \mathrm{m}$ & $0.38 \pm 0.02$ & $-0.5 \pm 0.2$ & $\mathrm{NA}$ \\
$<5 \mu \mathrm{m}$ & $0.53 \pm 0.02$ & $1.1 \pm 0.3$ & 1.6 \\
Reservoir & $0.48 \pm 0.03$ & $0.7 \pm 0.2$ & 1.2 \\
\hline
\end{tabular}


dent by changing the plane of focus during TEM inspection, revealing 2 distinct viral particles. The number of viruses in this presumptive lysing flagellate cell was ca. 15. Using this BS, mortality estimates for the entire flagellate community in situ and in the experiments would be 44 to $59 \%$, corresponding to 2.6 to $3.3 \times 10^{3}$ flagellate cells $\mathrm{ml}^{-1} \mathrm{~d}^{-1}$ lysed by viruses. Our observations and rate estimates suggest a potentially important role for viruses infecting HNFs. Targeted and intensive studies are needed to deepen our understanding of the dynamics of the viruses of HNFs.

Acknowledgements. This study was supported by the French Grant Agency under the research grant AQUAPHAGE (no. ANR 07 BDIV 015-06) to M.G.W. and the Grant Agency of the Czech Republic under the research grant 13-00243S awarded to K.Š.

\section{LITERATURE CITED}

Azam F, Fenchel T, Field JG, Gray JS, Meyer-Reil LA, Thingstad F (1983) The ecological role of water-column microbes in the sea. Mar Ecol Prog Ser 10:257-263

Bettarel Y, Sime-Ngando T, Bouvy M, Arfi R, Amblard C (2005) Low consumption of virus-sized particles by heterotrophic nanoflagellates in two lakes of the French Massif Central. Aquat Microb Ecol 39:205-209

Børsheim KY (1993) Native marine bacteriophages. FEMS Microbiol Ecol 102:141-159

Bratbak G, Haslund OH, Heldal M, Næss A, Røeggen T (1992) Giant marine viruses? Mar Ecol Prog Ser 85:201-202

> Brussaard CPD (2004) Viral control of phytoplankton populations - a review. J Eukaryot Microbiol 51:125-138

- Brussaard CP, Wilhelm SW, Thingstad F, Weinbauer MG and others (2008) Global-scale processes with a nanoscale drive: the role of marine viruses. ISME J 2:575-578

> Garza DR, Suttle CA (1995) Large double-stranded DNA viruses which cause the lysis of a marine heterotrophic nanoflagellate (Bodo sp.) occur in natural viral communities. Aquat Microb Ecol 9:203-210

> González JM, Suttle CA (1993) Grazing by marine nanoflagellates on viruses and viral-sized particles: ingestion and digestion. Mar Ecol Prog Ser 94:1-10

- Hahn MW, Höfle MG (2001) Grazing of protozoa and its effect on populations of aquatic bacteria. FEMS Microbiol Ecol 35:113-121

> Heldal M, Bratbak G (1991) Production and decay of viruses in aquatic environments. Mar Ecol Prog Ser 72:205-212

- Hennes KP, Suttle CA (1995) Direct counts of viruses in natural waters and laboratory cultures by epifluorescence microscopy. Limnol Oceanogr 40:1050-1055

> Jürgens K, Jeppesen E (2000) The impact of metazooplankton on the structure of the microbial food web in a shallow, hypertrophic lake. J Plankton Res 22:1047-1070

> Jürgens K, Arndt H, Zimmerman H (1997) Impact of metazoan and protozoan grazers on bacterial biomass distribution in microcosm experiments. Aquat Microb Ecol 12: 131-138
Lund JWG, Kipling C, Le Cren ED (1958) The inverted microscope method of estimating algal numbers and the statistical basis of estimation by counting. Hydrobiologia 11:143-170

- Massana R, Del Campo J, Dinter C, Sommaruga R (2007) Crash of a population of the marine heterotrophic flagellate Cafeteria roenbergensis by viral infection. Environ Microbiol 9:2660-2669

> Montagnes DJS, Barbosa AB, Boenigk J, Davidson K and others (2008) Selective feeding behaviour of key freeliving protists: avenues for continued study. Aquat Microb Ecol 53:83-98

Murray AG, Jackson GA (1992) Viral dynamics: a model of the effects of size, shape, motion and abundance of single-celled planktonic organisms and other particles. Mar Ecol Prog Ser 89:103-116

> Nagasaki K, Ando M, Imai I, Itakura S, Ishida Y (1993) Virus-like particles in an apochlorotic flagellate in Hiroshima Bay, Japan. Mar Ecol Prog Ser 96:307-310

> Sharoni, S Trainic, M Schatz, D Lehahn, Y and others (2015) Infection of phytoplankton by aerosolized marine viruses. Proc Natl Acad Sci USA 112:6643-6647

Šimek K, Kasalicky V, Jezbera J, Hornak K and others (2013) Differential freshwater flagellate community response to bacterial food quality with a focus on Limnohabitans bacteria. ISME J 7:1519-1530

Šimek K, Pernthaler J, Weinbauer MG, Hornák K, and others (2001) Changes in bacterial community composition, dynamics and viral mortality rates associated with enhanced flagellate grazing in a meso-eutrophic reservoir. Appl Environ Microbiol 67:2723-2733

Šimek K, Horňák K, Jezbera J, Nedoma J, Znachor P, Hejzlar J, Sed'a J (2008) Spatio-temporal patterns of bacterioplankton production and community composition related to phytoplankton composition and protistan bacterivory in a dam reservoir. Aquat Microb Ecol 51: 249-262

Šimek K, Nedoma J, Znachor P, Kasalický V, Jezbera J, Horňák K, Sed'a J (2014) 2014: A finely tuned symphony of factors modulates the microbial food web of a freshwater reservoir in spring. Limnol Oceanogr 59: 1477-1492

Sommer U, Adrian R, De Senerpoint Domis L, Elser JJ, and others (2012) Beyond the Plankton Ecology Group (PEG) model: mechanisms driving plankton succession. Annu Rev Ecol Evol Syst 43:429-448

Weinbauer MG (2004) Ecology of prokaryotic viruses. FEMS Microbiol Rev 28:127-181

Weinbauer MG, Fuks D, Peduzzi P (1993) Distribution of viruses and dissolved DNA along a coastal trophic gradient in the northern Adriatic Sea. Appl Environ Microbiol 59:4074-4082

> Weinbauer MG, Hornák K, Jezbera J, Nedoma J, Dolan JR, Šimek K (2007) Synergistic and antagonistic effects of viral lysis and protistan grazing on bacterial biomass, production and diversity. Environ Microbiol 9:777-788

Wen K, Ortmann AC, Suttle CA (2004) Accurate estimation of viral abundance by epifluorescence microscopy. Appl Environ Microbiol 70:3862-3867

- Winter C, Bouvier T, Weinbauer MG, Thingstad TF (2010) Trade-offs between competition and defense specialists in unicellular planktonic organisms: the 'killing the winner' hypothesis revisited. Microbiol Mol Biol Rev 74: $42-57$

Submitted: November 11, 2014; Accepted: July 31, 2015

Proofs received from author(s): September 25, 2015 